\title{
Strategije uljudnosti i neuljudnosti u ostavštini na turskom jeziku svećenika Gjure Adama Büttnera
}

\author{
MARTA ANDRIĆ* \\ • https://doi.org/10.31823/d.27.4.5 • \\ UDK: 811.512.161'1 • Izvorni znanstveni rad \\ Primljeno: 21. prosinca 2018. • Prihvaćeno: 2. prosinca 2019.
}

${ }^{*}$ doc. dr. sc. Marta Andrić, Filozofski fakultet

Sveučilišta u Zagrebu, Ivana Lučića 3, 10000 Zagreb, Hrvatska martaandric@yahoo.com

Sažetak: Gjuro Adam Büttner rođen je u Sommerachu 1714. godine i bio je svećenik biskupije Würzburg. Od 1744. do 1779. godine bio je svećenik Srijemske biskupije i prvi dijecezanski župnik u Zemunu nakon oslobođenja od Turaka. Njegova rukopisna ostavština na turskom jeziku pronađena je u knjižnici Đakovačko-osječke nadbiskupije. Ona se sastoji od jednoga njemačko-turskoga rječnika (128 stranica) te nekoliko manjih listića i sveščića posvećenih filološkim $i$ vjersko-didaktičkim temama. Svrha cijele ostavštine bio je misionarski i pastoralni rad, jer se Zemun tijekom Büttnerova župnikovanja nalazio na granici Habsburške Monarhije i Osmanskoga Carstva. Analiza fonološke, morfološke $i$ sintaktičke razine Büttnerova turskoga jezika pokazala je da je Büttner dobro poznavao turski i da je pratio neke od tendencija u razvoju jezika onovremenoga Istanbula. Analiza zastupljenosti strategija uljudnosti i neuljudnosti doprinijet će boljemu poznavanju turskoga jezika na samoj granici Osmanskoga Carstva te će dopuniti dosadašnje spoznaje o Büttneru i okolnostima u kojima je u Zemunu živio. Analizom je ustanovljeno da se Büttner uglavnom koristio strategijama neuljudnosti.

Ključne riječi: Gjuro Adam Büttner, turski jezik, transkribirani tekstovi, strategije (ne)uljudnosti.

\section{Uvod}

Gjuro Adam Büttner rodio se 1714. godine u današnjoj Njemačkoj u Sommerachu i bio je svećenik biskupije 
Würzburg. ${ }^{1}$ Friedrich Karl von Schönborn (1674. - 1746.), biskup biskupije Würzburg i Bamberg, 1744. godine poslao ga je u Zemun. Do toga je došlo jer se Beogradskim mirom 1739. godine granica između Osmanskoga Carstva i Habsburške Monarhije na tom području ustalila na Dunavu te je time Beograd pripao Osmanskomu Carstvu, a Zemun Austriji. Zemun je tad kao leno predan spomenutom biskupu von Schönbornu koji je potom poduzeo razne mjere kako bi grad uredio: to je podrazumijevalo i naseljavanje obrtnika s njemačkoga govornoga područja i slične mjere, a s tim doseljenicima, kao njihov dušobrižnik, u Zemun je stigao i Büttner. On je time postao svećenik Srijemske biskupije i prvi župnik u Zemunu po oslobođenju od Turaka. U Zemunu je ostao sve do svoje smrti 1779. godine.

U Büttnerovoj ostavštini koja je nakon njegove smrti prenesena u sjedište Srijemske biskupije, u Đakovo ${ }^{2}$, nalazila se i rukopisna građa na turskom jeziku. Ona se sastoji od jednoga velikoga njemačko-turskoga rječnika te četiri dodatna sveščića i tri listića, a danas se čuva u Središnjoj nadbiskupijskoj i fakultetskoj knjižnici u Đakovu. $^{3}$

Rječnik je naslovljen Türkisches Wörter-buch oder Dictionarium Seu Vocabularium i obaseže 126 stranica. Na svakoj stranici rječnika nalazi se između 25 i 30 natuknica, što znači da ukupno sadrži oko 3700 natuknica na njemačkome jeziku. Natuknice su složene abecednim redom. Njemački je jezik pisan goticom, a turski jezik (kao i sporadična pojašnjenja na latinskom, koji je služio kao metajezik) latinicom.

Četiri sveščića i tri listića čine sveukupno oko 50 ispisanih stranica teksta. I u njima je turski jezik pisan latinicom. Sadržaj listića može se podijeliti u dva dijela: jedan je filološki i s pomoću njega može se pratiti tijek Büttnerova učenja turskoga jezika, odnosno prikupljanja i koncipiranja građe za rječnik, a drugi je vjersko-poučni, katekizamski - očigledno namijenjen svećeničkom djelovanju, odnosno misionarskom radu. ${ }^{4}$

Kako je u Büttnerovoj ostavštini dio koji je na turskom jeziku pisan latinicom (a ne osmanskom arabicom, koja je bila pismo Osmanskoga Carstva), ona pripada skupini tzv. transkribiranih tekstova koji su vrlo važan izvor za povijest turskoga

\footnotetext{
${ }^{1}$ Opširnije o Büttneru i njegovoj ostavštini na turskom jeziku vidjeti u: M. ANDRIĆ, Rukopisna ostavština na turskom jeziku svećenika Gjure Adama Büttnera, Zagreb, 2015.

${ }^{2}$ Godine 1773. sjedinjene su Srijemska i Bosanska biskupija, a sjedište im je bilo u Đakovu.

${ }^{3} \mathrm{Na}$ tu me je ostavštinu upozorio mons. dr. sc. Marin Srakić, đakovačko-osječki nadbiskup u miru, zbog čega mu srdačno zahvaljujem.

${ }^{4} \mathrm{U}$ tom dijelu (koji obuhvaća oko 18 kartica teksta) nalaze se dva ispita savjesti, potom popis Deset Božjih zapovijedi, Pet crkvenih zapovijedi, Sedam svetih sakramenata, Sedam darova Duha Svetoga, Sedam djela milosrđa i Sedam glavnih grijeha, psalam broj 122 te jedan popis mogućih grijeha (također radi pripreme za ispovijed), a sve je to na turskom jeziku.
} 
jezika. Osmanska arabica bila je ortografski sustav koji nije bio u potpunosti prilagođen bilježenju fonoloških i morfonoloških obilježja turskoga jezika zbog čega ga na temelju tekstova pisanih arabicom nije moguće rekonstruirati. Stoga se upravo transkribirani tekstovi koji nisu pisani arabicom smatraju vrijednim izvorima za proučavanje fonologije turskoga jezika. Transkribirane tekstove sastavljali su i zapisivali stranci, autori neturskoga porijekla, koji su osmanski turski bilježili vlastitim pismom (latinicom, ćirilicom i dr.), a motivi za to mogli su biti razni: neki su od njih živjeli u Osmanskom Carstvu (najčešće u Istanbulu) kao trgovci, diplomati i slično, neki su u Osmansko Carstvo dospjeli kao zarobljenici; ${ }^{5}$ sastavljali su ih, naravno, i profesionalni prevoditelji (npr. dubrovački dragomani ${ }^{6}$ ), dok su primjerice bosanski franjevci učili i zapisivali osmanski turski kako bi mogli regulirati i održavati odnose s osmanskom vlašću. ${ }^{7}$

Na temelju sadržaja Büttnerove ostavštine može se zaključiti da je njegov glavni motiv za učenje turskoga - osim nesumnjive filološke strasti (uz materinski njemački poznavao je i latinski, talijanski i francuski) - bio misionarski rad. Analiza jezika rječnika i pomoćnih tekstova pokazala je da je Büttner ovladao gramatikom turskoga jezika. Obilježja njegova idiolekta uglavnom ne nose tragove turskih dijalekata ili varijeteta koji su bili prisutni na prostoru zapadnoga Balkana, što bi bilo očekivano, nego se temelje na gramatikama osmanskoga: analiza je pokazala da se koristio gramatikama Françoisa à Mesgniena Meninskoga ${ }^{8}$ i Jean-Baptistea Holdermanna ${ }^{9}$ te rječnikom Giovannija Molina ${ }^{10}$, odnosno da je njegov idiolekt utemeljen na jeziku naučenom s pomoću postojećih izvora. $K$ tomu, što je posebno zanimljivo, rezultati jezične analize pokazali su da je Büttner na neki način pratio razvoj i tendencije koje su u njegovo vrijeme postojale $\mathrm{u}$ istanbulskom turskom $\mathrm{i}$ uglavnom usvojio obilježja suvremenoga istanbulskoga turskoga.

${ }^{5}$ V. npr.: Gy. NÉMETH, Die türkische Sprache des Bartolomaeus Georgievits, u: Acta Linguistica Academiae Scientiarium Hungaricae 18(1968.)3-4, 263-271.

${ }^{6}$ V. MIOVIĆ, Dubrovačka diplomacija u Istambulu, Zagreb - Dubrovnik, 2003.

${ }^{7}$ E. ČAUŠEVIĆ, The Turkish Language in Ottoman Bosnia, Istanbul, 2014.

${ }^{8}$ F. à M. MENINSKI, Linguarum Orientalium Turcicae, Arabicae, Persicae Institutiones Seu Grammatica Turcica, Beč, 1680., M. ANDRIĆ, Rukopisna ostavština na turskom jeziku svećenika Gjure Adama Büttnera, 14-15., 23-26.

${ }^{9} \mathrm{~J}$-B. HOLDERMANN, Grammaire turque ou méthode courte et facile pour apprendre la langue turque avec un recueil des noms, des verbes, et des manières de parler les plus nécessaires á sçavoir avec plusieurs dialogues familiers (=Grammaire turque), Istanbul, 1730., M. ANDRIĆ, Rukopisna ostavština na turskom jeziku svećenika Gjure Adama Büttnera, 15., 26.

${ }^{10}$ G. MOLINO, Dittionario della Lingua Italiana Turchesca, Rim, 1641., M. ANDRIĆ, Rukopisna ostavština na turskom jeziku svećenika Gjure Adama Büttnera, 12., 26-27. 
Takav rezultat analize, koji je upućivao na to da je Büttner imao kontakt s govornicima turskoga jezika iz Istanbula, naknadno je potvrdilo jedno pismo objavljeno u Litteratur des katholischen Deutschlands, zu dessen Ehre und Nutzen, herausgegeben von katholischen Patrioten. Naime nakon Büttnerove smrti kurat zemunskoga lazareta Thomas Micklausich poslao je u Würzburg pismo s obavijesti o Büttnerovoj smrti uz molbu da se tamošnja zajednica vjernika moli za pokojnika. U tome pismu Micklausich hvali pokojnika i navodi kakvim je životom živio: »U njemu je blistala apostolska revnost, iznimna poniznost, ljubav za bližnjega i osobito za siromahe kakvu nije lako naći; stoga se i dogodilo da poslije svoje smrti nije ostavio gotovo ništa osim jedne neudane sestre, također siromašne i bolesne. Mogao je od njezinog Veličanstva uz malo nastojanja postići biskupsku čast; zaista, ako netko nije nikada za sebe tražio takve časti, on je bio taj.«Uz to spominje i sljedeće: »Kako bi tuđinske duše zadobio za nebo, naučio je istočnjački jezik pa je na njemu često slušao ispovijedi Armenaca koji su iz Turske prelazili u carske zemlje i poučavao ih kršćanskom nauku. ${ }^{11}$ Time je postalo jasno da je Büttner kao svećenik djelovao i među Armencima na području Beograda i Zemuna i da je s njima komunicirao na turskom jeziku te da su, po svemu sudeći, oni ti koji su njegovu idiolektu donijeli obilježja onovremenoga istanbulskoga turskoga. ${ }^{12}$

\section{Nova pitanja i novi pristupi}

$\mathrm{Na}$ taj su način riješena osnovna pitanja kojima je bila posvećena analiza turskoga jezika Büttnerove ostavštine, ali i dalje nisu dani odgovori na pitanja vezana uz okolnosti u kojima je nastala i u kojima je korištena. U ovome radu pokušat će se dati odgovor na jedno od tih pitanja, a to je kako se Büttner ophodio sa svojim sugovornicima na turskom jeziku, što bi trebalo dopuniti i sliku o njemu samom.

$\mathrm{Na}$ to pitanje odgovor se može ponuditi analizom jezika građe u okviru pragmatike, odnosno teorije jezične (ne)uljudnosti. No, da bi takva analiza dobila kontekst, u ovome će radu prvo biti opisane okolnosti u kojima se ta komunikacija

${ }^{11}$ Litteratur des katholischen Deutschlands, zu dessen Ehre und Nutzen, herausgegeben von katholischen Patrioten, III, Coburg, 1780., 387. Zahvaljujem dr. sc. Elmaru Hochholzeru koji me uputio na taj izvor. U prikazu knjige Rukopisna ostavština na turskom jeziku svećenika Gjure Adama Büttnera E. Hochholzer iznio je biografske podatke iz izvora o Büttneru prije njegova dolaska u Zemun: podatke o njegovu porijeklu, rođenju i školovanju. E. HOCHHOLZER, Georg Adam Büttner (1714. - 1779.) - Pfarer, Generalvikar und Verfasser eines deutsch-türkischen Wörterbuchs, Würzburger Diözesangeschichtsblätter, 81. Band, Würzburg, 2018., 323-341.

${ }^{12} \mathrm{Na}$ povezanost Büttnera s onovremenim Istanbulom upućuje i činjenica da se koristio ranije spomenutom Holdermannovom gramatikom: ta je gramatika objavljena 1730. godine u Istanbulu, a Büttner se njome koristio u Zemunu već dvadesetak godina kasnije. M. ANDRIĆ, Rukopisna ostavština na turskom jeziku svećenika Gjure Adama Büttnera, 26. i 129. 
odvijala: na temelju sadržaja teksta ostavštine bit će prikazano u kakvim je okolnostima Büttner živio u Zemunu, na granici dvaju carstava, i kako je on sâm vidio sredinu u kojoj je živio.

\section{Analiza sadržaja rečenica navedenih kao primjer uporabe}

Iz povijesnih izvora (najopširnije su među njima Kanonske vizitacije ${ }^{13}$ ) mogu se saznati osnovne informacije o Büttnerovu životu u Zemunu: doznaje se da je Büttner bio uspješan župnik i da je imao važno mjesto u hijerarhiji Srijemske biskupije, da je živio u skromnim uvjetima te da je Zemun u njegovo vrijeme bio šarolika, mnogoetnička sredina u kojoj nije bilo lako živjeti. ${ }^{14}$ Kako bi se u okolnostima u kojima je Büttner živio dobio uvid i iz njegove perspektive, u ovom će radu sam Büttnerov rječnik i građa na turskom jeziku koja je uz njega nađena biti analizirani kao povijesni izvor.

U tekstu rječnika mogao bi se radi toga analizirati izbor natuknica, ali kako se pretpostavlja da je Büttner za lijevu (njemačku) stranu rječnika imao (zasad neotkriven) uzor, takva analiza vjerojatno ne bi dala relevantne podatke. No uz natuknice - a opseg natuknica nije ujednačen i ovisi prije svega o autorovoj potrebi za obrazlaganjem i pojašnjavanjem natuknice - sporadično se nalaze rečenice kojima se oprimjeruju natuknice. Jednako tako i u filološkom dijelu u sveščićima nalaze se popisi riječi koji predstavljaju pripremnu fazu rada na rječniku, kao i razrade nekih gramatičkih tema (potaknute čitanjem gramatika kojima se Büttner koristio) u kojima se također navode rečenice kao primjeri uporabe.

U cijeloj građi nalazi se ukupno 444 takve rečenice: 29 u S1 $1^{15}, 9$ u S2, 106 u S4 i 300 u rječniku. 46 rečenica iz sveščića prepisano je u rječnik, što znači da građa sveukupno sadrži 398 rečenica.

28 rečenica jesu poslovice koje je Büttner zasigurno prepisao iz nekoga drugoga izvora jer su poslovice bile uobičajen dio priručnika za učenje jezika. Za sve ostale rečenice $s$ velikom se sigurnošću može reći da ih je sastavio sâm Büttner. To se može vidjeti prema sljedećem:

a) prema njihovu sadržaju (npr. u rečenicama se kao toponimi spominju Zemun i Beograd, gradovi koji su mu bili bliski)

\footnotetext{
${ }^{13}$ S. SRŠAN (ur.), Visitationes Canonicae - Kanonske vizitacije, Knjiga IV. Srijem, 1734. - 1768., Osijek - Đakovo, 2006.

${ }^{14} \mathrm{M}$. ANDRIĆ, Rukopisna ostavština na turskom jeziku svećenika Gjure Adama Büttnera, 17-18.

${ }^{15} \gg \mathrm{S} \ll$ je oznaka za $\gg$ sveščić $\ll$, a broj je broj sveščića.
} 
b) prema načinu na koji su nastale: primjerice u S4 nalaze se rečenice potaknute popisom »adverbia (što su uglavnom prilozi i postpozicije) iz spomenute gramatike Meninskoga, a uz svaki prilog koji je prepisao iz gramatike Büttner je dodao svoju rečenicu i tako pokazao kako ga primijeniti, npr. Erken - kalkmak ve erken jadmak saglukdr. (Rano - ustati i rano leći zdravo je.)

c) prema tomu što ih se - osim poslovica koje se može naći i u drugim priručnicima turskoga jezika - ne nalazi u gramatikama kojima se koristio ili sličnim onovremenim priručnicima turskoga jezika, što znači da ih nije iz njih prepisao.

U dosadašnjim radovima o Büttneru već je spomenuto da se u tekstu rječnika i ostale građe sadržajno mogu izdvojiti rečenice u kojima spominje toponime iz okolice Zemuna, potom rečenice u kojima opisuje Osmanlije ${ }^{16}$ te one koje govore o vjeri. U cijelom korpusu rečenica ukupno je 23 rečenice u kojima se spominju toponimi: od toga se u 14 rečenica spominju Beograd i Zemun ${ }^{17}$, što je bilo dovoljno da se Büttnerova ostavština prostorno smjesti. Rečenice koje su posvećene vjeri primjetno su brojne (ima ih 40, a pri tome se ne računa ranije spomenuti dio koji je u potpunosti vjersko-poučnoga karaktera, nego samo rečenice u filološkom dijelu građe). One se prema sadržaju mogu dodatno podijeliti na one koje iznose činjenice o vjeri i temeljne kršćanske istine (npr. Christosun Tevabileri oniki idiler. $(10)^{18}$ - Krist je imao dvanaest apostola.), na one pokorno-prijekornoga karaktera (npr. Ghünden ghüne daha ghünahkiar olurus. (S4.10) ${ }^{19}$ - Iz dana u dan sve smo grješniji.) i one posvećene nabrajanju mogućih grijeha (Itschmekde, jemekde lotuluk etdüm. (45) - Neumjereno sam pio i jeo.). U dvjema rečenicama (uz natuknicu stifften) spominje se i crkvena imovina:

(97) Bu adam kylisseje jüs forind vaküf etdi/bagladi/brakdy. Ovaj je čovjek crkvi darovao sto forinti.

\footnotetext{
${ }^{16}$ Rečenica koje govore o Osmanlijama ukupno je 15. Opisi Osmanlija koji su u njima izneseni redovito su negativni, npr. Frenk Osmanlidan daha akylidr Schifesys. (22) (Europljani su pametniji od Osmanlija, u to nema sumnje.) Više vidjeti u: M. ANDRIĆ, Rukopisna ostavština na turskom jeziku svećenika Gjure Adama Büttnera, 21.

${ }^{17}$ Npr. Paschanun aghrliki Belgrada gheldy. (15) (Pašin tovar stigao je u Beograd.); Duna taschdy, Zemünün idginde ghyrdi. (106) (Dunav se prelio i poplavio Zemun.) Od ostalih toponima u rečenicama se spominju još Beč $(2 x)$, Dunav $(2 x)$, Tisa $(2 x)$ i Sava $(1 x)$. U natuknicama se spominju i neki drugi toponimi, pa i iz okolice Zemuna, o čemu vidjeti više u: M. ANDRIĆ, Rukopisna ostavština na turskom jeziku, 19-20. Büttner ne spominje područje iz kojega je došao u Zemun, ali navodi rečenicu: Vilajetime ghitmee hassret csekeirim. (18) (Čeznem poći u svoj zavičaj.)

${ }^{18}$ Oznaka za broj stranice u rječniku.

${ }^{19}$ Oznaka za sveščić, broj sveščića i stranicu.
} 
(97) Bu kilisse bütün vaküf agcsesiyle japilmischdr. Ova je u crkva u potpunosti napravljena darovanim novcem.

Dvije rečenice govore o svećeničkoj svakodnevici:

(50) Vachtdur klisseje ghitmek. Vrijeme je da se pođe u crkvu.

(107) Ghüllecseghim gheldy kilissede, ghendumy sapt etdüm. (107) Došlo mi je u crkvi da se smijem, ali sam se suzdržao.

U korpusu se nalazi 39 rečenica kojima se opisuje gospodarsko stanje onoga vremena. Prevladavaju rečenice kojima se opisuje oskudno imovinsko stanje, i u zajednici i privatno. Na primjer:

(5) Bu jerun ghellilij azdur. Ovo mjesto ima slabe prihode.

(24) Veresi csok, para jok. Mnogo se robe daje na dug, a novaca nema.

(40) Ölefemden bir ackcse artramam. Od svoje plaće ne mogu uštedjeti ni novčića.

(50) Hasnada aghcse jokdur. U blagajni nema novaca.

(57) Deischderecseghim jokdur. ${ }^{20}$ Nemam drugu košulju. (Nemam košulju za promijeniti.)

(S1.1) Bu esnade ališ veriš köttdr. Trenutačno je trgovina loša.

Navedenu lošu ekonomsku sliku upotpunjuje i slika društva: od zanimanja i titula izrijekom se u rečenicama spominju vojnik (5x), poklisar $(3 \mathrm{x})$, paša $(3 \mathrm{x})$, ratnik $(3 \mathrm{x})$, car $(2 \mathrm{x})$, janjičar $(1 \mathrm{x})$, kalfa $(1 \mathrm{x})$ i sluga $(1 \mathrm{x})$, a najviše spomena ima lopov $(8 \mathrm{x})$ kojemu se može pridružiti i razbojnik $(2 \mathrm{x})$. U skladu s time među rečenicama koje opisuju životne okolnosti u 36 rečenica govori se o fizičkim napadima i nesigurnosti. Na primjer:

(106) Hyrsyslarün elinden gücsile siviśdum. Jedva sam se spasio iz ruku lopova.

(117) Bu adam on adamün ustüne sallar/icsine ghyrer/sokulur. Ovaj bi se čovjek usudio ići sam na desetoricu.

(118) Avurduma bir jumruk vurdu. Udario me šakom u obraz.

I u opisima ljudskih osobina prevladava negativna slika, na primjer:

(4) Bu adamy jüsünden seserim chyrsys olmasyna. Ovome čovjeku na licu vidim da je lopov.

(S4.10) Her hande fena adam eksik deildr. Nigdje ne nedostaje loših ljudi.

${ }^{20}$ Značenje te rečenice na turskom može se ustanoviti tek prema navedenom njemačkom prijevodu: »Ich kann der Hemmet nit wechslen. hab keins mehr.« 
Uslijed takvih negativnih i nesigurnih okolnosti u 11 rečenica izražava se borba za red i pravdu, na primjer:

(39) Hyrsyslar sapt olunmaslarsa, bundan biter ki kimse Emmin deilder. Ako lopovi ne budu pohvatani, to znači da nitko nije siguran.

(40) Benden on florind aldün, ghetir, jerine ko. Uzeo si od mene deset forinti, donesi ih, vrati ih na mjesto.

(59) Hyrsyslukdan ib doghar. Lopovluku slijedi konopac. (Tko krade, bit će obješen.)

Unatoč takvim okolnostima nailazi se i na rečenice koje govore o pozitivnim stranama društvenoga života. Takvih je rečenica 14, na primjer:

(21) Dostümlen ghürüschdum. Vidio sam se sa svojim prijateljem.

(S1.6) Hatyrinusy sormagha gheldum. Došao sam pitati vas kako ste.

(S4.10) Csokdan dostumy gürecsegim gheldi. Odavna sam poželio vidjeti svoga prijatelja.

Sliku o ljepšoj strani svakodnevice dopunjuju i rečenice (ukupno 7) u kojima su opisani obrazovanje i intelektualni interesi. Sudeći po tim rečenicama, područje Büttnerova interesa bili su, očekivano, turski jezik, ali i znanje o svemiru. Na primjer:

(4) Ben sana türkcse ögreterim. Naučit ću te turski jezik.

(109) Akylün ne kesser? Göghü katsch mil usakdr Toprakdan? Kako ti procjenjuješ? Koliko je milja nebo daleko od zemlje?

(110) Ben bulurum, aklila jetischirum, ki ghünesch Top-ghülesy ghibi ghiter/jürür. Ja shvaćam i razumijem da sunce ide / kreće se poput topovske kugle.

(122) Eilenmegh icsin okuirum. Čitam kako bih se zabavio.

U dosad navedenim područjima izdvojeno je 213 rečenica (od ukupno 398). Preostale rečenice ne mogu se tako transparentno grupirati: one čine mnoštvo manjih sadržajnih skupina i također pružaju uvid u svakodnevicu. Na primjer:

(5) Bu hastalükda csok eridüm. Sav sam oslabio od ove bolesti.

(5) Halee/Taschera ghiterim. Idem u zahod. / Idem van.

(32) Ajaghüma Tiken gyrmisch/batmisch. U nogu mi se zabio trn.

(55) Baschinda bir tel/kyl kalmamisch. Na glavi mu nije ostala ni jedna vlas/dlaka.

(112) Aji dahi alischmamiś, jabanydr. Medvjed se još nije pripitomio, divlji je.

(S4.10.) Usakda ghemiler ghörünürler. U daljini se vide brodovi. 
Upitne i usklične rečenice prenose razgovorni diskurs, na primjer:

(26) Mumun burnuny kes. Odreži vrh svijeće!

(28) Bu adamy selamla. Pozdravi ovoga čovjeka!

(72) Ismin nedr? Kako se zoveš?

(79) Jol sahmetlery nicse? Koliki su troškovi puta?

(111) Sahat kacsdedr? Koliko je sati?

(120) Bu kośkiametde nereje ghitersyn? Kamo ćeš po ovoj mećavi?

(S4.10.) Bir az gheri dur/csekil. Povuci se malo unatrag!

Dosad navedene rečenice nemaju primarno pragmatičku funkciju, ali se iz njihova izbora može iščitati stav autora te donekle rekonstruirati njegov pogled na sredinu i okolnosti u kojima je živio, što predstavlja kontekst za analizu strategija (ne)uljudnosti u tekstu ostavštine.

\section{Analiza (ne)zastupljenih strategija (ne)uljudnosti}

Područje jezične uljudnosti jest interdisciplinarno područje istraživanja u kojem se prepliću lingvistika, sociologija, socijalna psihologija i antropologija. Tradicionalno se ono smatra potpodručjem pragmatike. Istraživanje jezične uljudnosti odnosi se na istraživanje načina na koji su osjećaji i svijest o sebi govornika i sugovornika u komunikaciji podržani ili ugroženi. Primjerice učinak molbe ili kritike može biti ublažen izborom riječi, a taj izbor riječi ovisi o odnosu među sugovornicima i društvenom okruženju kojemu pripadaju. ${ }^{21}$

Izražavanje uljudnosti kao društveni čin sastoji se i od jezičnih i od nejezičnih elemenata i nastaje na temelju interakcije, te stoga istraživanje izražavanja uljudnosti omogućuje uvid u društvene prakse koje se vežu uz individualnu upotrebu jezika. ${ }^{22}$

Istraživanje uljudnosti u jeziku počelo se razvijati sedamdesetih godina prošloga stoljeća $^{23}$, a posebno se intenziviralo nakon 1987. godine kad su Penelope Brown

${ }^{21}$ Definicija je navedena prema: D. Z. KÁDÁR, J. CULPEPER, Historical (Im)politeness: An Introduction, Historical (Im) politeness, 2011., Bern, 9-36., 9.

${ }^{22}$ Isto, 9.

${ }^{23}$ Tad je »utemeljiteljica moderne teorije uljudnosti Robin Lakoff, zaslužna za inauguraciju isključivo pragmatičkoga opisa te kategorije «, uljudnost definirala »kao sustav interpersonalnih relacija organiziran s ciljem olakšavanja interakcije umanjivanjem mogućnosti sukoba i konfrontacije svojstvenih svim oblicima međuljudske komunikacije (Lakoff 1990: 34)«. M. MATEŠIĆ, D. M. KIŚ, Pragmatika gramatičkih oblika: morfološka i sintaktička sredstva kao načini za iskazivanje uljudnosti, u: Fluminiensia 27(2015.)2, 103-116., ovdje 104. 
and Stephen C. Levinson u knjizi Politeness: Some Universals in Language Usage ${ }^{24}$ izložili okvir koji i danas ima značajan utjecaj na tom području. U središtu njihove teorije nalazi se koncept $o b r a z^{25}$ u smislu ugleda ili slike o sebi. Obraz je isto što i osjećaj pojedinca o vlastitoj vrijednosti, a može biti ugrožen ili opravdan u komunikaciji s drugima.

Teorija o izražavanju uljudnosti koju su predstavili Brown i Levinson sugerirala je da svaki razuman sudionik u interakciji nastoji izbjeći govorne činove koji ugrožavaju obraz ili pak primjenjuje određene strategije kako bi minimizirao ugrožavanje. ${ }^{26}$ Broj strategija definiran je u okviru teorije uljudnosti: on je ograničen, a govornik bira strategije koje će uvažiti potrebe obraza sugovornika. ${ }^{27}$

Godine 1996. Johnatan Culpeper opisao je novo polje: istraživanje jezične neuljudnosti. Sukladno strategijama uljudnosti utvrdio je strategije kojima se ostvaruje neuljudnost te ga je primijenio i u sinkronijskom i u dijakronijskom istraživanju neuljudnosti. ${ }^{28}$

U zadnjih desetak godina istraživanje (ne)uljudne upotrebe jezika razvilo je diskurzivni pristup, odnosno kontekstualnu analizu izražavanja (ne)uljudnosti. Fokus je na sljedećim pitanjima: kako iskaz doživljavaju sudionici komunikacije, i govornik i sugovornik; smatraju li ga uljudnim ili neuljudnim; na temelju čega donose takve zaključke, odnosno koje informacije i znakovi dovode do zaključka je li netko bio uljudan ili neuljudan. Dakle (ne)uljudna upotreba jezika više nije podrazumijevala sustav izražavanja koji govornik svjesno izabire, nego se analiza usmjerila na način na koji se u konkretnoj govornoj situaciji zaključuje što se smatra uljudnom odnosnom neuljudnom upotrebom jezika. ${ }^{29}$

U odnosu na istraživanje modernih jezika istraživanja jezične (ne)uljudnosti u povijesti koja se provode u okvirima historijske pragmatike novijega su datuma i broj je takvih radova manji. Svrha povijesnih istraživanja (ne)uljudnosti jest opis i komparativna analiza (ne)uljudnosti u povijesnom kontekstu, registriranje promjena u izražavanju (ne)uljudnosti te prilagođavanje postojećih teorija i istraživačkih

\footnotetext{
${ }^{24}$ P. BROWN, S. C. LEVINSON, Politeness: Some Universals in Language Usage, Cambridge, 1987.

${ }^{25}$ Prijevod engleskoga termina face. U hrvatskim radovima o uljudnosti taj termin prevodi se kao 'lice', a prijevod 'obraz' korišten je u literaturi na bosanskom jeziku (v. npr. S. BAKŠIĆ, Strategije učtivosti u turskom jeziku, Sarajevo, 2011.). U ovom radu priklanjamo se potonjem prijevodu.

${ }^{26}$ Isto, ii.

${ }^{27}$ Pregled strategija uljudnosti može se vidjeti u: J. CULPEPER, Politeness and Impoliteness, u: K. AIJMER, G. ANDERSEN (ur.), Sociopragmatics. Handbooks of Pragmatics, V, Berlin, 391-436.

${ }^{28}$ J. CULPEPER, Towards an Anatomy of Impoliteness, u: Journal of Pragmatics 25(1996.), 349-367.

${ }^{29}$ Linguistic Politeness Research Group (ur), Introduction: The Linguistic Politeness Research Group, u: Discursive Approaches to Politeness, Berlin, 2011., 5.
} 
okvira povijesnom kontekstu. Nedostatak je takvih istraživanja u tome što nema mogućnosti praćenja uživo ili potpune rekonstrukcije konteksta u kojem se ostvaruju govorni činovi. Upravo se zbog toga u povijesnim istraživanjima (ne)uljudnosti primjećuje širok raspon varijacija u prilagodbi postojećega teorijskoga pristupa konkretnoj analizi.

Analizom zastupljenosti strategija (ne)uljudnosti u Büttnerovim tekstovima uočeno je, prije svega, da se za mnoge strategije ne može reći jesu li bile primijenjene ili nisu jer korpus zbog svoje ograničenosti ne pruža tu vrstu informacija. No na temelju strategija koje jesu zastupljene moglo se zaključiti da se kod Büttnera strategije uljudnosti krše, a strategije neuljudnosti primjenjuju.

\subsection{Strategije Uljudnosti}

Strategije uljudnosti kod Büttnera uglavnom nisu zastupljene. Stoga je bilo potrebno najprije ustanoviti jesu li te strategije bile prisutne u drugim tekstovima sličnim Büttnerovu. Tekstovi s kojima je provedena poredba bili su tursko-latinski razgovornik ugarskoga plemića Jakaba Nagyja de Harsányja, objavljen u Brandenburgu 1762. godine pod naslovom Colloquia Familiaria Turcico-Latina: seu Status Turcicus Loquens $^{30}$, te ranije spomenuta gramatika turskoga jezika Jean-Baptistea Holdermanna. U navedenim tekstovima, kao i kod Büttnera, analizirano je izražavanje molbe i naredbe te uporaba honorifika.

U Harsányjevu razgovorniku u rečenicama kojima se izriču molbe i naredbe, odnosno u rečenicama koje sadrže imperativ, utvrđene su sljedeće strategije uljudnosti: strategija konvencionalizirane indirektnosti (pri čemu je molba izrečena, ali se sugovorniku ostavlja dovoljno prostora da je odbije), strategija ograde (što podrazumijeva jezična sredstva kojima se sugovorniku signalizira da ga se ne želi prisiljavati), strategija umanjivanja prinude (pri čemu se sugovorniku sugerira da usluga koja se od njega traži nije osobito velika) te strategija isprike (kojom se govornik ispričava sugovorniku zbog pritiska koji na njega vrši). ${ }^{31} \mathrm{Na}$ primjer:

Bir ßahat iol deha vardur. Csok degil, zabrejle, tezanda iz..$^{32}$ Imamo još sat vremena puta. Nije mnogo, strpi se, brzo ćemo stići.

Bujurunuz itseri, her sej hazirdur, ev güzel, temiz ve ßigsak. ${ }^{33}$ Izvolite unutra, sve je spremno, kuća je lijepa, čista i topla.

\footnotetext{
${ }^{30}$ Gy. HAZAI, Das Osmanisch-türkische im XVII. Jahrhundert. Untersuchungen an den Transkriptionstexten von Jakab Nagy de Harsány, Budimpešta, 1973.

${ }^{31}$ Prema: J. CULPEPER, Politeness and Impoliteness, i S. BAKŠIĆ, Strategije učtivosti.

${ }^{32}$ Gy. HAZAI, Das Osmanisch-türkische im XVII. Jahrhundert, 64.

${ }^{33}$ Isto, 66.
} 
Ludfiejle göndür tez, lazum olagsak sejleri gyötürsünler. ${ }^{34}$ Molim te, pošalji brzo (nekoga) da donese potrebne stvari.

Mazur bujur, sultanum, hem bir ez ßabrejle. ${ }^{35} \mathrm{Ne}$ zamjeri, gospodaru, i malo se strpi.

Kod Büttnera molbe i naredbe izriču se bez primjene navedenih strategija, na primjer:

(25) Kaur schu kestene. Ispeci ove kestene!

(28) Hatsch csikar. Prekrsti se!

(98) Agsyny tik. Začepi mu usta!

(116) Ei sakla, sakün kaibetmejesyn. Dobro spremi, pazi da ne izgubiš!

(115) Dibine jasyl. Potpiši se!

Samo u jednoj rečenici primijenjena je strategija umanjivanja prinude (uvođenjem priloga malo):

(12) gisvi bekle. Malo pričekaj.

Kako se i prema navedenim primjerima može vidjeti, nemodificirana direktnost u izražavanju molbi i naredbi obilježje je Büttnerova idiolekta. Njegov turski idiolekt zasigurno se oblikovao po uzoru na onaj njemački, pa se može pretpostaviti da se Büttner tim strategijama nije koristio ni u materinskom jeziku ili da se koristio reducirano. No vrlo je moguće da je izostanku navedenih strategija u njegovu turskom pridonijelo i njegovo rudimentarno poznavanje turskoga jezika, odnosno nepoznavanje jezičnih sredstava kojima bi se navedene molbe i zabrane ublažile. Ono pak što se u usporedbi s drugim transkribiranim tekstovima iz navedenih (i drugih sličnih) rečenica posebno jasno vidi jest zaključak da Büttner na turskom nije slušao ili razgovarao s nekim tko bi u odnosu na njega bio na društvenoj ljestvici viši od njega, nego s onima nižim od sebe, te je u skladu s time osmislio primjere za svoj rječnik i oblikovao svoj idiolekt.

Pretpostavku da su Büttnerovi (su)govornici na turskom jeziku bili manje ugledni od njega potvrđuje i korištenje honorifika koje je u teoriji jezične (ne)uljudnosti obuhvaćeno strategijom pokazivanja poštovanja: kod Büttnera je ono vrlo reducirano. U njegovu je rječniku navedeno nekoliko titula kao rječnička natuknica, npr. elći (poklisar), hasnadar (rizničar), padišah (car), pascha (paša), reis-effendi (reisefendija), vekil (zastupnik), no za većinu tih titula poprilično je sigurno da u Zemu-

\footnotetext{
${ }^{34}$ Isto, 72 .

${ }^{35}$ Isto.
} 
nu nije imao mogućnosti njima se koristiti, odnosno da nije imao sugovornikâ koje bi tim titulama oslovio.

Kako je već spomenuto, Büttner se, učeći turski jezik, koristio Holdermannovom gramatikom. U toj gramatici u drugom njezinu dijelu navedeni su dijalozi koji ilustriraju razgovorne situacije istanbulskoga svakodnevnoga života. ${ }^{36}$ Sudionici tih dijaloga međusobno se oslovljavaju sljedećim riječima: agha (aga), soultanum ${ }^{37}$ (gospodaru), tchelebum (gospodine).

Kod Büttnerra se i riječ aga javlja samo kao titula ${ }^{38}$. Titula sultan javlja se samo jednom i to kao njemački prijevod za riječ padišah ${ }^{39}$. Titula čelebi navodi se također samo jednom i to kao prijevod za natuknicu Artig, wohlgestalt (10), što opet ne sugerira da bi se njome koristio u oslovljavanju sugovornika.

Iz navedenoga se može zaključiti da se Büttner koristio Holdermannovom gramatikom kao izvorom za znanje o gramatici, ali ne i kao izvorom za znanje o svakodnevnoj komunikaciji. Taj dio očito nije privukao njegovu pozornost. Može se zaključiti i to da na temelju pregleda cjelokupne građe ne možemo znati kako bi Büttner oslovio svoga sugovornika, što bi moglo značiti da mu taj dio i nije bio važan, pa ga nije ni obradio, odnosno uključio u svoje zapise. Konačno, može se reći da Büttner u svoje tekstove na turskom jeziku nije uklopio sadržaje koji bi mu omogućili primjenu ranije spomenute strategije pokazivanja poštovanja koja podrazumijeva oslovljavanje sugovornika honorificima.

\subsection{Strategije neuljudnosti}

Za razliku od strategija uljudnosti, koje su analizirane prema svojoj nezastupljenosti, strategije neuljudnosti mogu se analizirati prema zastupljenosti. $U$ daljem tekstu bit će analizirane strategija zastrašivanja (odnosno usađivanja uvjerenja da će se dogoditi što štetno po sugovornika), strategija ugrožavanja tuđega prostora (u ovom slučaju u prenesenom smislu: zahtijevanjem informacija koje su intimne i inzistiranjem na tome da se o njima govori) te strategija upozoravanja na sugovornikov dug. ${ }^{40}$

\footnotetext{
${ }^{36}$ J.-B. HOLDERMANN, Grammaire turque, 144-194.

${ }^{37}$ Titulom sultan nije se koristilo (samo) kao titulom vladara, odnosno cara, nego za oslovljavanje osoba kojima se iskazuje poštovanje.

${ }^{38} \mathrm{Npr}$. Rittmeister prevodi kao Spahilar-agasy. Atlylar-agasy (spahijski aga, konjanički aga), 80.

${ }^{39}$ Der Bottschaffer hat beym Sultan Audienz gehabt. Elći Patischahile buluschdy (Izaslanik se susreo s carem.), 11.

${ }^{40}$ Prema: J. CULPEPER, Towards an Anatomy of Impoliteness.
} 
Te su strategije zastupljene i u filološkom dijelu, ali uglavnom u rečenicama koje su vezane uz vjeru i odgoj u vjeri, na primjer.:

(4) Ghiünahdan, fena amelerden ikrah olurmysyn? Kaješ li se zbog (svojih) grijeha i nedjela?

No navedene su strategije posebno naglašene u onom dijelu koji nije filološki, nego je vjersko-poučni. Već je rečeno da taj dio sadrži dva teksta pripreme za ispovijed, odnosno dva ispita savjesti, koji se nalaze u S2 i S3. Upravo je u tim tekstovima primjena strategija neuljudnosti izrazito naglašena. Kao prvi primjer koji to potvrđuje može se navesti rečenica kojom se vjernika uvodi u ispit savjesti. Ta je rečenica koncipirana kao zastrašivanje sugovornika koji se priprema za ispovijed, sugovornik pri tome doznaje što će mu se dogoditi ako ne prizna sve svoje grijehe:

(S2.2) Uldükdan sorah dschehenem idschinde ghiunahlarun sajarsyn, puschman olursyn, aglarsyn, san birißi faida olmas, Sana hitsch faida calmas. Dschehenemun ebbeti kappileri Senun usdune kitlendukdan Sorah oki atschilmas her vakid, her saaman. Nakon što umreš, brojat ćeš svoje grijehe u paklu, kajat ćeš se, plakati, nitko ti ne će pomoći, ne će ti biti pomoći niotkuda. Nakon što se vječna vrata pakla za tobom zatvore, vrata koja se nikada ne otvaraju.

Nakon takvoga uvoda slijedi preispitivanje, odnosno podsjećanje sugovornika na njegove moguće grijehe, pri čemu je on dužan priznati koje je od navedenih grijeha počinio. U tom je dijelu uvelike prisutna druga i treća navedena strategija: ulaženje u tuđi (intimni) prostor i upozoravanje na sugovornikov dug. I iz samoga teksta koji sugovornika, odnosno kandidata, priprema za ispovijed jasno je da njemu ta situacija nije ugodna:

(S2.5) Ondan sorah Insan! baschlairsyn chostuavanank olursyn, csümle ghiunahlarun Sakün, bische eksik suillersyn, jahud artuk, ve togriden bische bragmajasyn/saklamajesyn, udanmejesyn, senun kabahatun usdune, bische saklameyesyn eghier korkdun ve udandün senun chostuavanankun jokdur, fenader, Allah kabul etmeß. Potom, čovječe, počinješ $s$ ispovijedi i to svih svojih grijeha. Pazi, nemoj da bi rekao manje ili više i nemoj ništa skrivati, nemoj se stidjeti zbog svojih pogrješaka. Nemoj ništa skrivati, a ako se uplašiš i postidiš, ništa od tvoje ispovijedi, ne će biti valjana, Bog je ne će prihvatiti.

U S2 priprema za ispovijed sadržajno prati, odnosno redom obrađuje svaku od Deset Božjih zapovijedi, a pisana je u obliku uputa svećeniku, pri čemu mu se sugerira što sve treba pitati kandidata. Stoga svaka cjelina počinje ovakvim ili sličnim tekstom:

(S2.13) Lasum kyhana usdune Sualletsyn choßtuavank olan adama, Eghier bosdi bu vaßieti fighir ilen jahud Sosilen, jahud Ischlemeile. Potrebno je da svećenik pita čo- 
vjeka koji se ispovijeda je li griješio protiv navedene zapovijedi mišlju, riječju ili djelom.

Nakon toga slijede opisi mogućih grijeha:

(S2.11) Eghier uschaklari var, ve eghier denbelluk etdi beslemesinde. Eghier Eteb/Edeb ukredmedi ghendlerini, va lasum olan Schei Xrißtosun jolluni - dini ustune. Eghier ukredi ghendlerine kiötti/fenab jol, hem kabahat Ischlemesine. Eghier ghiendi kabahat ischledi uschaklari ukunde, Eghier malluni daghetti, oinamailen, bekrilukilen, Sargoschlukilen, ve bu ghiunah evelki ghiunahdan bujukder. Ako ima djecu, a nemaran je u njihovu uzdržavanju. Ako ih nije učio moralnom ponašanju i onomu što je neophodno: Kristovu putu i njegovoj vjeri. Ako ih je upućivao na loš put, učio ih da čine nedjela. Ako je i sam činio nedjela pred djecom, ako je rasipao imovinu kockom, razvratom i pijanstvom, to je grijeh i gori od ranije spomenutoga.

Za razliku od S2, u S3 grješne situacije opisane su u prvom licu jednine, kao da ih već izgovara sam sugovornik. Na primjer:

(S3.7) Duvamy bitürmemišim / hics etmemišim, aklum fighrüm kairi jerlere ve scheilere ghestirmišim, ghünahlarümün afyni ve ǵennetlüghy dilememišim, dünialük istemišim. Nisam dovršio molitvu / uopće se nisam molio, mislio sam na druga mjesta i stvari dok sam se molio, nisam tražio oprost za svoje grijehe niti sam se molio da dospijem u raj, nego sam želio svjetovne stvari.

Nakon pitanja koja se odnose na njegovanje vjerskoga života prelazi se i na propitivanje situacija iz intimnoga života, na primjer:

(S3.9) Kullaghimile csok kierre szina etmišim, jani edepsis lakrdilar, türküler, sösler meǵilislerde ǵani ghöülden dignemišim. Mnogo sam puta bludno griješio slušajući: na mjestima za druženje rado sam slušao nepristojne priče, pjesmice i anegdote.

Analiziraju se i međuljudski odnosi, na primjer:

(S3.8) Guercsek elimle adamy üldürmemišim, amma/lakin fighrümile basi düšmanlarümün/hassymlerümün ölümini istemišim, ah öleidi ol hasmim demischim, jahot birisi onu üldüreidi/gheberdeidi/jogheteidi, onün elinden kurtulaidüm! Vlastitom rukom nisam nikoga ubio, ali sam u mislima nekima od svojih neprijatelja želio smrt, govorio sam: $\gg$ Ah, da barem umre taj moj neprijatelj ili da ga netko ubije/zatuče/uništi, da ga se riješim! «

Konačno, navode se i moguće grješne situacije iz poslovnoga života:

(S3.10) Ališda verišde csok nahak scheiler etmišim, siate almišim, eksik vermišim, csok haramkiarlük etmišim, ister ülćmede, ister hisapda, defterde. U trgovini sam počinio 
mnogo nepravde: uzimao sam previše, davao manje nego što treba, varao sam i u mjerenju, i u računanju, i u vođenju računa.

Nakon što je ispit savjesti završen, još se jednom primjenjuje strategija zastrašivanja kako bi kandidat za ispovijed priznao sve grijehe:

(S2.21) bir daha tuschun budunianun datlißi / Sevkini tes ghetscher ve kasanarsyn Sana Sgendsche, ki hitsch ghetschmes, ve eghier olum seni aldi bu ghiunahilen, tes bularsyn Seni dschenem-atesch idschinde budrki ondan csikmak / kurdolmak jokdr, nitsche ki csok adamlarun baschuna ghieldi, ve Senden csok ghiunah ischlemediler, laikin Senun ghiunahun onlardan csokdr. Još jednom razmisli: dražest i užitci ovoga svijeta brzo će proći i ti ćeš sebi priskrbiti muku koja nikada ne prolazi, a ako te smrt uzme s ovim grijehom, brzo ćeš se zateći usred paklene vatre iz koje nema izlaska ni spasa: mnoge je ljude to snašlo, a nisu griješili više od tebe - štoviše, ti si veći grješnik od njih.

Primjena navedenih strategija u ovom kontekstu nije svojstvena samo Büttneru, nego je uobičajena za tu vrstu tekstova; štoviše, može se pretpostaviti da je Büttner pri sastavljanju ovdje citiranih tekstova imao uzor na njemačkom ili nekom drugom jeziku. Među sudionicima koji u ovom slučaju komuniciraju - a to su svećenik i vjernik koji se priprema za ispovijed - ne postoji ravnopravnost. Da su sugovornici ravnopravni, to bi bili potencijalno konfliktni govorni činovi. No sugovornik se u ovome slučaju svjesno podređuje, ali i očekuje nagradu (oprost od grijeha, duhovni spokoj, raj i sl.). Utoliko bi u ovom slučaju ugrožavanje sugovornikova obraza primjenom navedenih strategija neuljudnosti, koliko god tijekom svoje realizacije za njega bilo neugodno, u konačnici sugovorniku trebalo koristiti.

\section{Zaključak}

Analiza zastupljenosti strategija (ne)uljudnosti pokazala je da je Büttner u ostavštini opažene strategije neuljudnosti primjenjivao, a strategije uljudnosti kršio. Za situacije u kojima se primjenjuju strategije neuljudnosti karakteristična je neravnoteža u moći sugovornika, odnosno nadmoć jednoga od sugovornika. Crkveni jezik i diskurs, koliko je poznato, zasad još nije analiziran s tog aspekta, no poznato je da su strategije neuljudnosti zastupljene u jeziku vojske ${ }^{41}$ i u sudnici ${ }^{42}$, gdje jedan ili više sudionika komunikacije imaju veću moć od sugovornika. Ritualna narav ovdje

\footnotetext{
${ }^{41} \mathrm{U}$ svojem prvom radu u kojem opisuje strategije neuljudnosti i time uvodi taj pojam J. Culpeper kao primjer opisuje jezik vojske (u poglavlju pod naslovom Impoliteness in an army training camp). J. CULPEPER, Towards an Anatomy of Impoliteness, 359-364.

${ }^{42}$ S. HARRIS, The Limits of Politeness Re-visited: Courtroom Discourse as a Case in Point, u: Linguistic Politeness Research Group (ur.), Discursive Approaches to Politeness, Berlin - Boston, 2011., 85-109.
} 
opisanih komunikacijskih situacija dodatno pojačava razliku u moći između govornika i sugovornika. No, s obzirom na to da se sugovornik svojevoljno podređuje, računajući na svoju konačnu korist, ne može se govoriti o disensnom govornom činu i utoliko se opisana primjena strategija neuljudnosti razlikuje od onih koje rezultiraju konfliktnom komunikacijom i u kojima je sugovornik oštećen.

Kad se sagleda cjelokupna ostavština, s obzirom na sadržaj, jasna je razlika između filološkoga, rječničkoga dijela i onoga dijela kojemu je očita svrha vjersko, misionarsko djelovanje. No u obama tim područjima Büttner se izražavao kao svećenik, a to je u komunikaciji podrazumijevalo njegovu nadređenost sugovorniku. Takav je način komuniciranja vjerojatno podržavala i zahtijevala i sredina u kojoj je živio. Zemun, kako se vidjelo iz primjera rečenica iz ostavštine, nije bio ugodna sredina za život, a neugodne situacije koje se ondje moglo doživjeti nesumnjivo su utjecale i na način komuniciranja stanovnika toga grada. $\mathrm{K}$ tomu, sudeći prema izostanku strategija uljudnosti kojima bi se ublažilo izricanje naredbi te izostanku honorifika u njegovim tekstovima, može se zaključiti da je Büttner na turskom jeziku uglavnom komunicirao s onima koje je na društvenoj ljestvici smatrao nižima od sebe, odnosno da su govornici turskoga jezika koje je imao priliku slušati i od njih učiti jezik bili iz nižih društvenih slojeva. 


\title{
STRATEGIES OF POLITENESS AND IMPOLITENESS IN GEORG ADAM BÜTTNER'S MANUSCRIPT LEGACY IN THE TURKISH LANGUAGE
}

\author{
Marta ANDRIĆ*
}

Summary: Georg (Gjuro) Adam Büttner was born in Sommerach in 1714 and was a priest of the Diocese of Würzburg. From 1744 to 1779, he served as the priest of the Diocese of Srijem and he was the first diocesan pastor in Zemun after the liberation from the Turks. His manuscript legacy in the Turkish language was found in the Diocesan Library in the Diocese of Đakovo and Osijek (Đakovo, Croatia). Büttner's legacy includes a German-Turkish Dictionary (128 pages), and several smaller papers and volumes dealing with philological and religious-didactic topics. The purpose of his entire legacy was missionary and pastoral work, because during his ministry as a pastor, Zemun was on the border between the Habsburg Monarchy and the Ottoman Empire. The phonological, morphological and syntactic analysis of Büttner's Turkish language showed that Büttner was well acquainted with the Turkish language and aware of some basic tendencies present in the development of the then Istanbul dialect. The analysis of the strategies of politeness and impoliteness used in his legacy will contribute to the better understanding of the Turkish language on the border of the Ottoman Empire and will complete the present knowledge about Büttner's life and the circumstances in which he lived in Zemun. The analysis showed that Büttner used mostly strategies of impoliteness.

Keywords: Georg Adam Büttner, the Turkish language, transcribed texts, strategies of (im)politeness.

\footnotetext{
* Asst. Prof. Marta Andrić, Ph. D., University of Zagreb, Faculty of Humanities and Social Sciences, Ivana Lučića 3, 10000 Zagreb, Croatia, martaandric@yahoo.com
} 